\title{
Perbaikan Nilai Nutrisi Jerami Padi Melalui Suplementasi Tepung Daun Lamtoro pada Sapi Peranakan Ongole Jantan
}

\author{
S. D. Widyawati \\ Program Studi Peternakan, Fakultas Pertanian, Universitas Sebelas Maret \\ Jl. Ir. Sutami 36A, Surakarta 57126
}

\begin{abstract}
ABSTRAK
Percobaan ini dilakukan di desa Gentan, Bekonang Kabupaten Sukoharjo menggunakan sapi PO jantan sebanyak 9 ekor. Sapi dibagi ke dalam 3 perlakuan ransum, setiap perlakuan diulang 3 kali. Ransum basal digunakan jerami padi (JP) sebagai ransum kontrol (P0), P1 disusun dari P0 +tepung daun lamtoro(TDL) dan tepung daun ketepeng (TDK) dan P2 disusun dari P0 +tepung daun lamtoro(TDL) dan minyak ikan lemuru (MIL). Suplementasi TDL baik dengan TDK dan MIL nyata $(\mathrm{P}<0.05)$ meningkatkan konsumsi ransum, hal ini menunjukkan adanya perbaikan proses fermentasi microbial dalam rumen. Selanjutnya efek suplementasi ini akan meningkatkan kecernaan BK $(\mathrm{P}<0.01)$ dan SK $(\mathrm{P}<0.05)$ ransum. Kecernaan SK terbaik justru terjadi pada ransum kontrol, keadaan ini dapat dijelaskan bahwa mikrobia rumen akan berkembang tergantung dari substrat yang tersedia dalam rumen. Serat kasar (SK) sebagai sumber energi bagi ternak sapi, namun kemungkinan tidak diikuti dengan tersedianya sumber $\mathrm{N}$ sehingga tingginya SK yang tercerna tidak diikuti dengan perbaikan performan terlihat dari rendahnya pertambahan bobot badan yang dihasilkan. Kesimpulan yang dapat diambil bahwa suplementasi tepung lamtoro baik dengan tepung dan ketepeng maupun minyak ikan lemuru mampu memperbaiki nilai nutrisi jerami padi dan sangat dianjurkan.
\end{abstract}

Kata kunci : lamtoro, kecernaan, performan, sapi PO, ketepeng, minyak ikan lemuru

\section{Improvement of Nutritive Value of Rice Straw by Addition of Lamtoro Leave Meal to Beef Cattle}

\section{ABSTRACT}

Since rice straw is seasonal and low quality roughage, a supplementation for it is needed. Lamtoro leave meal (LLM), having both soluble and by-pass protein so, its enough potential to supply nutrients for optimize of rumen microbes and improving animal performance. When fed to animals with high portion of roughage can affect methane production highly, an adding reduction methane agent for it is needed, like ketepeng leave meal (KLM) and lemuru fish oil (LFO). Supplementation with LLM significantly increased dry matter and crude fiber intake $(p<0.05)$. This fact showed that LLM supplementation optimized rumen fermentation by microbes. Comparison between LLM-KLM and LLM-LFO to basal diet clearly showed that basal diet is the lowest ( $p<0.01)$ performance $(0.19$ vs $0.21 ; 0.23 \mathrm{~kg} / \mathrm{h} / \mathrm{d})$, however, the animal fed basal diet degraded crude fiber was significant $(p<0.05)$ higher $(74.49$ vs $69.02 ; 65.17 \%)$. It is apparent from this experiment that supllementation with lamtoro leave meal by adding both ketepeng leave meal and lemuru fish oil as a reduction methane agent are palatable, fermentable and reasonably digestible. It is recommended to use rice straw as a supplement.

Key words : Lamtoro, digestibility, performance, PO beef cattle, ketepeng and lemuru fish oil 


\section{PENDAHULUAN}

Jerami padi merupakan limbah pertanian yang sangat potensial sebagai sumber pakan serat bagi ternak ruminansia. Namun ketersediaannya sangat tergantung pada musim. Serat yang terkandung didalamnya terdiri atas selulosa yang telah mengalami lignifikasi lanjut dan telah terjadi kristalisasi dengan kadar silika yang cukup tinggi, sehingga nilai nutrisinya sangat jelek. Formula pakan seperti ini tentunya tidak bisa diharapkan bahwa ternak akan tumbuh secara baik dan optimal. Kendala lain yang dijumpai pada peternakan rakyat bahwa pola pikir yang sederhana dan apa adanya, penjualan ternak dilakukan pada saat membutuhkan dana dan daya beli konsentrat sangat rendah. Sebagaimana yang dinyatakan oleh Direktorat Budidaya Peternakan (2004) bahwa masalah umum pengembangan peternakan di Indonesia adalah sistim dan usaha budidaya peternakan kurang berorientasi kepada pasar dan profit, terkait dengan usaha sambilan, skala ekonomi dan orientasi produksi.

Dari berbagai kendala yang ada, maka penelitian ini didesain untuk memperbaiki kualitas pakanjerami padi dengan meningkatkan efisiensi penggunaan pakan kualitas rendah melalui suplementasi daun lamtoro. Lamtoro merupakan leguminosa pohon yang digunakan sebagai tanaman pagar atau penghijauan di perkotaan.Daun lamtoro mempunyai nilai nutrisi yang cukup baik. Kandungan nutrien bahan pakan ini terdiri atas PK 23\% dan TDN 60\%. Sutardi (1993) menyatakan bahwa daun lamtoro mengandung protein yang bersifat bypass selain protein yang soluble. Sehingga diharapkan selain mampu menumbuh kembangkan mikrobia rumen juga mampu menyumbangkan protein pasca rumen.

Jika ransum yang diberikan pada ternak sebagian besar terdiri atas hujauan atau pakan serat, maka gas metan yang diproduksi cukup tinggi. Yusiati dkk (1998) menyatakan bahwa penggunaan daun ketepeng dan minyak ikan lemuru mampu menekan produksi gas metan dengan menghambat bakteri metanogenesis, karena daun ketepeng mengandung kuinon dan minyak ikan lemuru mengandung asam lemak tak jenuh yang akan berikatan dengan ion hidrogen sehingga pembentukan gas metan akan tertekan.

\section{MATERI DAN METODE}

Percobaan ini telah dilakukan di Kandang Sapi milik Peternak di desa Gentan, Bekonang Kabupaten Sukoharjo menggunakan sapi PO jantan sebanyak 9 ekor. Sapi dibagi ke dalam 3 perlakuan ransum, setiap perlakuan diulang 3 kali. Ransum basal digunakan jerami padi (JP) sebagai ransum kontrol (P0), P1 disusun dari P0 + tepung daun lamtoro (TDL) dan tepung daun ketepeng (TDK) dan P2 disusun dari P0 + tepung daun lamtoro (TDL) dan minyak ikan lemuru (MIL).

Analisis bahan percobaan dilakukan di Laboratorium Ilmu Nutrisi dan Makanan Ternak, Jurusan Peternakan Fakultas Pertanian UNS. Analisis kandungan nutrient bahan percobaan dilaksanakan dengan menggunakan analisis proksimat mengikuti pedoman dari AOAC (1980).

Tabel 1. Komposisi dan kandungan nutrien pakan suplemen

\begin{tabular}{lcccccc}
\hline \hline \multicolumn{1}{c}{ Pakan } & BK & PK & EE & SK & Abu & TDN $\left.^{* *}\right)$ \\
\hline Suplemen TDL-DK & 80,23 & 27,14 & 4,75 & 9,91 & 11,23 & 70,11 \\
Suplemen TDL-MIL & 80,65 & 26,83 & 5,57 & 6,65 & 9,27 & 75,82 \\
Jerami Padi & 32,79 & 2,19 & 2,36 & 17,06 & 6,50 & 48,54 \\
\hline Keterangan : ${ }^{*} \begin{array}{l}\text { estimasi TDN } \\
\text { 1991) }\end{array}$ & $59.68-1.08 S K+0.3136 \mathrm{PK}+1.22 \mathrm{~L}+0.2508 \mathrm{BETN}$ (Sutardi,
\end{tabular}


Tabel 2. Kandungan nutrien ransum percobaan (\% BK )

\begin{tabular}{cccccc}
\hline \hline $\begin{array}{c}\text { Ransum } \\
\text { Percobaan }\end{array}$ & Protein kasar & Lemak & Serat kasar & Abu & TDN \\
\hline $\mathrm{P}-0$ & 7,34 & 6,61 & 47,91 & 20,05 & 49,81 \\
$\mathrm{P}-1$ & 17,69 & 3,17 & 18,56 & 14,17 & 75,26 \\
$\mathrm{P}-2$ & 17,63 & 3,33 & 17,91 & 13,77 & 76,40 \\
\hline
\end{tabular}

Evaluasi nilai nutrisi jerami padi (JP) melalui suplementasi tepung daun lamtoro baik ditambahkan tepung daun ketepeng maupun minyak ikan lemuru sebagai agensia reduksi metan, dilakukan dengan mengkaji beberapa pangukuran terhadap jumlah pakan yang dikonsumsi. Banyaknya pakan yang dikonsumsi akan mencerminkan perbaikan nafsu makan ternak sebagai akibat dari suplementasi tersebut. Kecernaan Bahan Kering (BK) dan serat kasar (SK) diukur untuk mengetahui adanya perbaikan kondisi rumen sehingga pencernaan fermentative oleh mikrobia rumen menjadi lebih optimal. Hasil akhir penelitian ini diharapkan adanya perbaikan performan ternak dilihat dari pertambahan bobot badan harian $(\mathrm{PBBH})$ yang ditunjukkan oleh sapi percobaan.

\section{Kecernaan Nutrien}

Penentuan nilai kecernaan nutrien yang meliputi kecernaan Bahan kering (BK), bahan organik (BO), protein kasar (PK) dan serat kasar (SK) ransum dilakukan dengan metode koleksi total feses (Tillman et al., 1989). Penentuan nilai kecernaan nutrien ini dilakukan selama 7 - 10 hari dengan periode adaptasi dan pendahuluan selama 14 hari.

Pada tahap koleksi, dilakukan pengukuran terhadap jumlah ransum yang dikonsumsi, sisa ransum, dan ekskresi feses. Sisa ransum dan feses dikoleksi kemudian ditimbang jumlah total sisa dan jumlah total feses, pekerjaan ini dilakukan setiap hari pada jam yang sama. Selanjutnya dilakukan pengambilan sampel setelah dihomogenkan dengan menggunakan mixer (untuk feses) ditimbang dan dikeringkan dibawah sinar matahari. Setelah kering ditimbang lagi untuk mendapatkan berat kering feses, setelah satu minggu dikomposit dan diambil sampel lagi untuk analisis nutrien di laboratorium yaitu BK, BO dan SK. Analisis nutrien ini juga dikerjakan untuk ransum yang diberikan dan sisa ransum.

\section{Pertumbuhan Ternak.}

Pertumbuhan diukur dengan menimbang bobot badan ternak dalam kurun waktu tertentu. Pengukuran ini menunjukkan seberapa besar ransum yang dikonsumsi oleh ternak akan digunakan untuk mensintesis jaringan tubuhnya dengan imbangan $\mathrm{N}$ yang positif.

Konsumsi ransum (berdasarkan bahan kering) ransum diukur setiap hari dengan menghitung selisih antara jumlah ransum yang diberikan dikurangi dengan sisa ransum yang diperhitungkan dengan dasar BK.

Penimbangan bobot badan dilakukan setiap 2 minggu sekali dan untuk mengetahui efisiensi ransum dihitung efisiensi penggunaan ransum dengan membagi antara pertambahan bobot badan dan konsumsi ransum dalam sataun waktu yang sama kemudian dikalikan $100 \%$.

\section{Hasil dan Pembahasan}

Respon sapi PO terhadap suplementasi TDL dalam pakan basal jerami padi ditinjau dari jumlah pakan yang dikonsumsi, nilai kecernaan dan performan pertumbuhannya dapat dilihat pada Tabel 3.

Ternak akan mengkonsumsi pakan sebanyak kebutuhannya. Jumlah pakan yang dikonsumsi pada ransum kontrol (P0) nyata $(\mathrm{P}<0.05)$ paling rendah dibandingkan perlakuan P1 dan P2, suplementasi TDL mampu meningkatkan jumlah pakan yang dikonsumsi. Keadaan ini dapat dijelaskna bahwa jerami padi mempunyai kualitas yang rendah, selain kandungan nutrien yang rendah juga 
Tabel 3 . Respon sapi PO terhadap suplementasi daun lamtoro dalam ransum

\begin{tabular}{llll}
\hline \multicolumn{1}{c}{ Peubah } & \multicolumn{1}{c}{ P0 } & \multicolumn{1}{c}{ P2 } \\
\hline Konsumsi BK & $3.42^{\mathrm{a}}$ & $4.40^{\mathrm{b}}$ & $4.57^{\mathrm{b}}$ \\
Kecernaan BK & $44.45^{\mathrm{A}}$ & $50.12^{\mathrm{B}}$ & $50.35^{\mathrm{B}}$ \\
Konsumsi PK & $0.30^{\mathrm{A}}$ & $0.60^{\mathrm{C}}$ & $0.56^{\mathrm{B}}$ \\
Kecernaan PK & $55.01^{\mathrm{A}}$ & $62.53^{\mathrm{AB}}$ & $62.98^{\mathrm{B}}$ \\
Konsumsi SK & $1.32^{\mathrm{a}}$ & $1.56^{\mathrm{b}}$ & $1.46^{\mathrm{b}}$ \\
Kecernaan SK & $74.49^{\mathrm{b}}$ & $69.02^{\mathrm{a}}$ & $65.17^{\mathrm{a}}$ \\
PBBH & $0.190^{\mathrm{A}}$ & $0.213^{\mathrm{B}}$ & $0.228^{\mathrm{B}}$ \\
\hline
\end{tabular}

Keterangan : Nilai rata-rata yang bersuperskrip huruf kecil yang berbeda pada baris yang sama menunjukkan berbeda nyata $(\mathrm{P}<0.05)$ Nilai rata-rata yang bersuperskrip huruf besar yang berbeda pada baris yang sama menunjukkan berbeda nyata $(\mathrm{P}<0.01)$

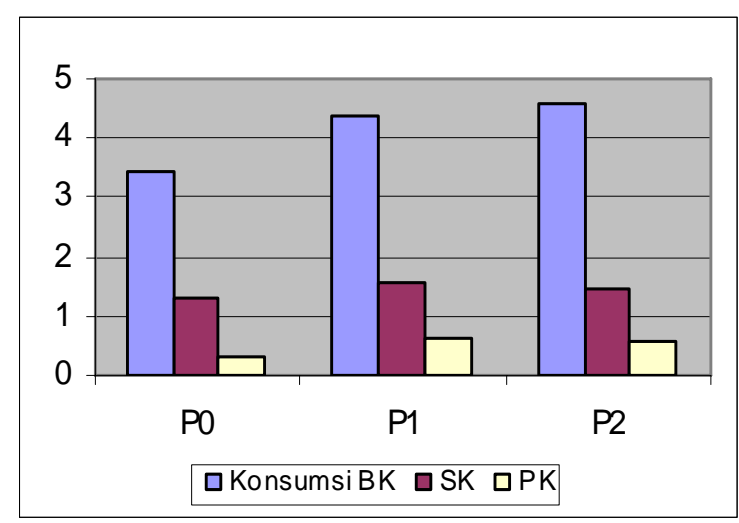

Gambar 1. Pengaruh suplementasi TDL dalam ransum berbahan dasar jerami padi terhadap konsumsi BK, PK dan SK ransum

disebabkan karena proses lignifikasi lanjut yang terjadi pada pakan serat ini. Rendahnya pakan yang dikonsumsi pada perlakuakn ini karena sifat bulky yang dimiliki jerami padi sehingga akan memenuhi ruang lambung, selanjutnya kapasitas fisik lambung ini akan membatasi jumlah pakan yang dikonsumsi.

Seiring meningkatnya jumlah pakan yang dikonsumsi, ternyata kecernaan $\mathrm{BK}$ dan PK. Meningkat secara signifikan $(\mathrm{P}<0.01)$. Suplementasi TDL baik dengan DK maupun MIL mampu memperbaiki lingkungan rumen sehingga akan mampu mengoptimalkan sintesis mikroba rumen yang akan beraktivitas dalam mencerna pakan serat.

Tabel 2 menggambarkan peningkatan kandungan PK ransum dengan adanya suplementasi TDL (7.34\% vs $17.69 \%$ dan 17.63\%). Meningkatnya kandungan PK ini akan meningkat pula degradasi protein dalam rumen yang akan mengakibatkan peningkatan konmsentrasi amonia. Sebagaimana yang dinyatakana oleh Sutardi (1978) bahwa amonia merupakan nhasil akhir degradasi protein oleh mikroba rumen. Konsentrasi yang optimal untuk pertumbuhan dan perkembangan mikrobia rumen sebesar 3.54 - $7.14 \mathrm{mM}$ (Satter dan Slyter, 1977; Sutardi, 1978; Ørskov, 1992). Konsentrasi amonia dalam rumen sebesar 98.3 mg\% ternyata tidak lagi merangsang pertumbuhan mikroba (Sutardi, 1979). Selanjutnya dinyatakan bahwa konsentrasi amonia maksimal untuk terjadinya degradasi karbohidrat sebesar $235 \mathrm{mg} / \mathrm{L}$ cairan rumen 
(Mehrez et al., 1977). Mikroba rumen yang mampu memanfaatkan amonia sebagai sumber $\mathrm{N}$ sebanyak $82 \%$ dari total mikroba rumen (Sutardi, 1978).

Mikrobia rumen (bakteri dan protozoa) mempunyai nilai nutrisi yang sangat baik ditinjau dari nilai BV (biological value), NPU (net protein utilization) dan TDC (true rigestible coefficient) nya (Sutardi, 1978). Sedangkan Johnson (1980) menjelaskan bahwa mikrobia rumen dalam mensuplai kebutuhan protein bagi induk semang sekitar $60-80 \%$ dari total kebutuhan proteinnya.

Terjadi perbaikan kecernaan BK dan PK secara sangat nyata $(\mathrm{P}<0.01)$ dengan suplementasi TDL. Suplementasi TDL baik dengan menambahkan DK maupun MIL dapat memperbaiki proses fermentasi microbial dalam rumen. Keadaan ini dapat menunjukkan bahwa mikrobia dalam rumen dapat tumbuh dan berkembang dengan lebih baik dibandingkan pada sapi yang hanya diberikan JP saja. Hal ini didukung oleh pendapat Afzalani, dkk (1999) karakteristik degradasi protein daun lamtoro sebesar $31.80 \%$, protein yang sulit larut tetapi potensial terdegradasi sebesar $34.21 \%$ sedangkan laju degradasinya $0.042 \% / j a m$. Selanjutnya ditambahkan bahwa efektif degradasi protein daun lamtoro sebesar 51.63\%. Sejalan dengan pendapat tersebut, Sutardi (1993) menjelaskan bahwa daun lamtoro mengandung protein yang bersifat solubel dan tahan degradasi dalam rumen (bypass protein) dengan nilai kecernaannnya sebesar $49.78 \%$. Namun dilihat dari kecernaan SK tertinggi pada P0 sedangkan P1 dan P2 nyata $(\mathrm{P}<0.05)$ lebih rendah dan keduanya berbeda tidak nyata. Pada sapi yang hanya diberikan JP saja memungkinkan untuk tumbuh dan berkembangnya mikrobia selulolitik dan hemiselulolitik. Mikrobia rumen dapat tumbuh dan berkembang dengan dukungan dari substart yang tersedia.

Serat kasar merupakan sumber energi utama bagi ternak ruminansia. Proses pencernaannya dalam rumen oleh mikrobia rumen akan menghasilkan VFA (Volatile Fatty Acids), yang terdiri atas asam asetat, asam propionat dan asam butirat. VFA ini akan digunakan sebagai energi bagi induk semangnya untuk proses pertumbuhannya. Kenyataan yang dapat dilihat pada percobaan ini bahwa tingginya kecernaan SK tidak diikuti dengan perbaikan performan sapi. Sapi yang diberi pakan P0 menghasilkan pertambahan bobot badan harian $(\mathrm{PBBH})$ yang sangat nyata paling rendah $(\mathrm{P}<0.01)$ dibandingkan $\mathrm{P} 1$ dan P2 (0.190 kg/ekor/hari) vs 0.213 dan 0.228 kg/ekor/hari). Selain energi, pertumbuhan ternak dilihat dari proses sintesis jaringan tubuhnya membutuhkan sumber protein. Sinkronisasi penyediaan protein dan enenrgi sangat mutlak untuk terjadinya sintesis jaringan tubuh (Widyobroto et al., 1999). Diduga pada sapi yang hanya diberi JP ternyata pasokan prtein pasca rumennya lebih rendah dibandingkan kedua pakan lainnya sehingga PBBH sapi PO yang diberikan JP saja tidak memperlihatkan performan yang baik.

Pertambahan bobot badan harian sapi PO yang diberi pakan basal saja (jerami padi) memperlihatkan kurangnya pasokan nutrien terutama untuk mencukupi kebutuhan energi dan proteinnya. Suplementasi TDL dalam pakan basal tersebut ternyata mampu memperbaiki lingkungan rumen maupun menyediakan nutrien pasca rumen yang dapat dimanfaatkan oleh ternak untuk pertumbuhannya. Sebagaimana yang dinyatakan oleh Sutardi (1979) bahwa daun petai Cina ternyata mempunyai daya tahan protein yang tinggi padahal bahan organiknya sangat mudah difermentasi. Selanjutnya dinyatakan bahwa nilai indeks ketahanan (resistivity index) protein daun petai Cina sebesar 0.409, semakin rendah nilai ini semakin tahan terhadap degradasi dalam rumen. Sehingga rekomendasi yang diberikan oleh Sutardi (1979) bahwa sumber protein yang ideal untuk ternak ruminansia adalah yang mampu menunjang pertumbuhan maksimal mikroba rumen, sebagian besar tahan terhadap degradasi mikroba rumen dan bernilai hayati (BV=biological value) atau utilisasi protein neto (NPU=net protein utilization) tinggi. 


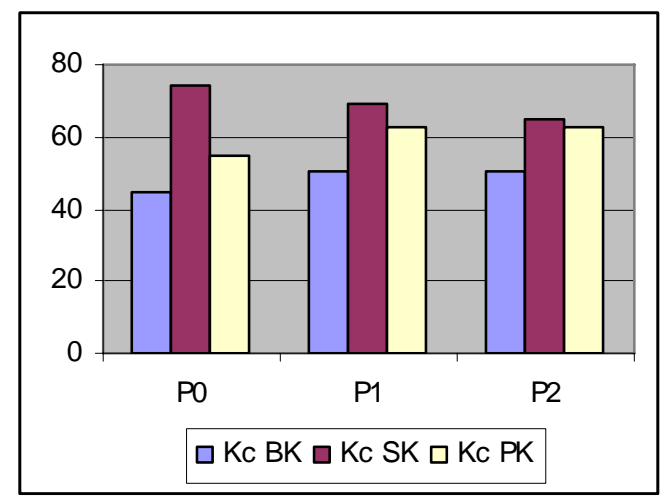

Gambar 2. Pengaruh suplementasi TDL dalam ransum berbahan dasar jerami padi terhadap kecernaan BK, PK dan SK ransum

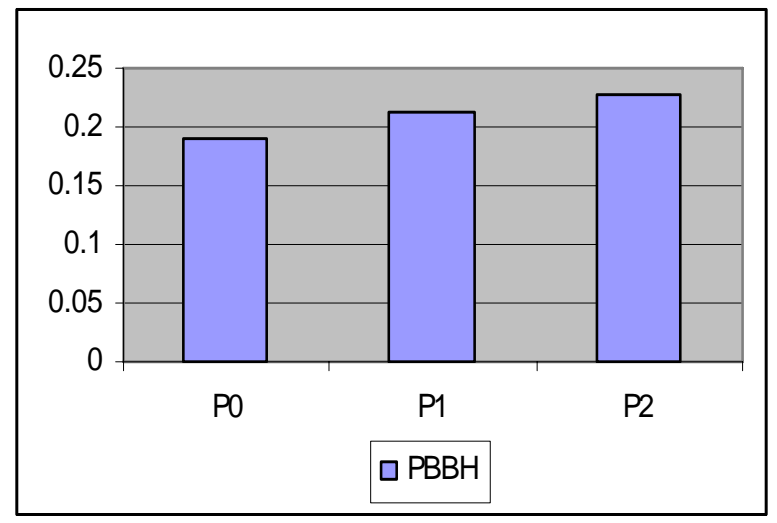

Gambar 3. Pengaruh suplementasi TDL dalam ransum berbahan dasar jerami padi terhadap pertambahan bobot badan sapi

\section{KESIMPULAN}

Suplementasi tepung daun lamtoro pada pakan jerami padi sangat diperlukan selain untuk memperbaiki proses biofermentasi dalam rumen juga menyediakan nutrien pasca rumen sehingga pertumbuhan ternak yang optimal dapat dicapai.

\section{DAFTAR PUSTAKA}

Afzalani, T.Kaswari dan A. Yani. 1999. Kajian Berbagai Sumber Protein Pakan Berdasarkan Ketahanannya Terhadap Degradasi Oleh Mikroba Rumen. Laporan Penelitian. Fakultas Peternakan UNJA. Jambi.

Association of Official Analysis Chemist. 1980. Official methods of analysis of the Association of Official Analytical Chemist. 13th ed.
Association of Official Analytical Chemist, Washington, DC.

McDonald, P., R.A. Edward and J.F.D. Greenhalgh. 1988. Animal Nutrition. $4^{\text {th }}$ edition. English Language Book Society, Longman, London.

Mehrez, A.Z., E.R. Ørskov and I. McDonald. 1977. Rate of rumen fermentation in relation to ammonia concentration. Brit.J.Nutr. 38:437.

Ørskov, E.R. 1992. Protein Nutrition in Ruminants. Second edition. Academic Press. London.

Satter, L.D. and L.L. Slyter. 1974. Effects of ammonia concentration on rumen microbial protein production in vitro. Brit.J.Nutr. 32:199.

Sunarso. 1984. Mutu Protein Limbah Agro-Industri Ditinjau dari Kinetika Perombakannya Oleh Mikroba Rumen dan Potensinya Dalam Menyediakan Protein Bagi Pencernaan Pasca Rumen. Thesis. Program Pasca Sarjana, IPB. Bogor. 
Sutardi, T. 1978. Ikhtisar Ruminologi. Dept. Ilmu Makanan Ternak, Fakultas Peternakan IPB. Bogor.

Sutardi, T. 1979. Ketahanan protein bahan makanan terhadap degradasi oleh mikroba rumen dan manfaatnya bagi peningkatan produktivitas ternak. Pros. Seminar Penelitian dan Penunjang Peternakan, LPP. Bogor.

Sutardi, T. 1993. Peningkatan Produksi Ternak Ruminansia Melalui Amoniasi Pakan Bermutu Rendah dan Suplementasi Sumber Protein Tahan Degradasi Rumen. Laporan Penelitian Hibah Bersaing I/1, Fakultas Peternakan IPB, Bogor.

Widyobroto B.P., S. Padmowijoto, dan R. Utomo. 1997 Pendugaan kualitas protein 60 bahan pakan untuk ternak ruminansia. Laporan Penelitian. Fakultas Peternakan UGM, Yogyakarta.

Widyobroto B.P. 1998. Transit Partikel dan Cairan dalam Saluran Pencernaan Sapi Perah Produksi
Tinggi yang Mendapat Ransum dengan Aras Konsentrat Berbeda. Buletin Peternakan., Volume 22, Hal. 168-178 Fakultas Peternakan UGM; ISSN : 0126-4400.

Widyobroto BP., SPS. Budhi, A. Agus and B. Santosa. 1999. Effect of undegraded protein level on nutrient digestibility and microbial protein synthesis of dairy cows. In : Lobley GE, A. White and JC. MacRae. (Ed). Protein metabolism and nutrition. Book of abstracts of the VIIIth International Symposium on Protein and Metabolism. P. 72. EAAP publication Wageningen Holland.

Widyobroto B.P. 1999. Pengaruh Tipe Karbohidrat dan Aras Undegraded Protein terhadap Konsumsi, Kecernaan Nutrien dan Parameter Fermentasi Rumen Sapi Peranakan Friesian Holstein, Buletin Sintesis Nomor : 11 Tahun VII, Agustus 1999, Hal. 1-8 , Yayasan Dharma Agrika Semarang. 